\title{
Microbial Natural Products in Drug Discovery
}

\author{
Ahmed S. Abdel-Razek ${ }^{1, *} \mathbb{\infty}$, Mehrez E. El-Naggar ${ }^{2, *} \mathbb{\infty}$, Ahmed Allam ${ }^{3}$, Osama M. Morsy ${ }^{4}$ and \\ Sarah I. Othman ${ }^{5}$ \\ 1 Microbial Chemistry Department, Genetic Engineering and Biotechnology Research Division, \\ National Research Centre, 33 El Buhouth st., Dokki, Giza 12622, Egypt \\ 2 Textile Research Division, National Research Centre, 33 El Bohouth st., Dokki, Giza 12622, Egypt \\ 3 Department of Zoology, Faculty of Science, Beni-Suef University, Beni-Suef 65211, Egypt; \\ ahmedalyallam@gmail.com \\ 4 Arab Academy for Science, Technology \& Maritime Transport, Arab League, Cairo 2033, Egypt; \\ ossama.morsy22@gmail.com \\ 5 Biology Department, College of Science, Princess Nourah Bint Abdulrahman University, \\ Riyadh 11671, Saudi Arabia; sialothman@pnu.edu.sa \\ * Correspondence: as.abdelgalil@nrc.sci.eg (A.S.A.-R.); mehrezeelnaggar@gmail.com (M.E.E.-N.); \\ Tel.: +0020-115-139-9008 (A.S.A.-R.); +0020-112-601-8116 (M.E.E.-N.)
}

Received: 25 February 2020; Accepted: 1 April 2020; Published: 16 April 2020

\begin{abstract}
Over a long period of time, humans have explored many natural resources looking for remedies of various ailments. Traditional medicines have played an intrinsic role in human life for thousands of years, with people depending on medicinal plants and their products as dietary supplements as well as using them therapeutically for treatment of chronic disorders, such as cancer, malaria, diabetes, arthritis, inflammation, and liver and cardiac disorders. However, plant resources are not sufficient for treatment of recently emerging diseases. In addition, the seasonal availability and other political factors put constrains on some rare plant species. The actual breakthrough in drug discovery came concurrently with the discovery of penicillin from Penicillium notatum in 1929. This discovery dramatically changed the research of natural products and positioned microbial natural products as one of the most important clues in drug discovery due to availability, variability, great biodiversity, unique structures, and the bioactivities produced. The number of commercially available therapeutically active compounds from microbial sources to date exceeds those discovered from other sources. In this review, we introduce a short history of microbial drug discovery as well as certain features and recent research approaches, specifying the microbial origin, their featured molecules, and the diversity of the producing species. Moreover, we discuss some bioactivities as well as new approaches and trends in research in this field.
\end{abstract}

Keywords: natural products; microbial products; drug delivery

\section{Introduction}

\subsection{Historical Overview of Natural Products in Drug Discovery}

Nature sustains unlimited resources of novel bioactive molecules, and the study of these resources is very useful in the process of drug discovery [1]. These bioactive molecules are called natural products (NPs). Natural products are metabolites and/or by-products derived from living organisms, such as plants, animals, and microorganisms [2]. Natural products have played an intrinsic role in human life for thousands of years. Due to their low cost and availability, natural products have been used as a source of medicine, especially in developing countries. Moreover, they are chemically diverse with various bioactivities and are the most valuable sources of drug discovery and development [3]. 
According to the World Health Organization (WHO), about $60 \%$ of the world's population depends on traditional medicine for their health care [4-9]. It is possible that the use of natural products as medicinal agents predates the earliest recorded history when humans used various and specific plants to cure diseases [10]. The oldest records dating to ancient Mesopotamia (2600 BC) described about 1000 plants and plant-derived materials, such as the oils of Cedrus species (cedar) and the juice of the poppy seed Papaver somniferum [11].

The ancient Egyptian Ebers Papyrus (1550 BC) contains about 800 complex prescriptions and more than 700 natural substances, such as Aloe vera (aloe) and the oil of Ricinus communis (castor) [12]. The famous Greek physicians and pharmacists collected hundreds of natural agents and plant-derived medicines and described their usage [13].

The Chinese are the leaders in the use of natural products in remedies. The oldest collection of Chinese herbs is Shen Nung Pen Ts'ao, which lists 385 materials. The Pen Ts'ao Ma catalogue (1573-1620) mentions 1898 herbal drugs and 8160 prescriptions. The number of medicinal herbs used in China reached 5967 in 1979. One of the most famous Chinese traditional herbs is the ginseng root Panax ginseng, which is used for health maintenance and treatment of various diseases. Other traditional Chinese medicines (TCM) include the extract of Ginkgo biloba, which can improve memory and sharpen mental preparedness, and the Indian hemp plant, Cannabis sativa, which has mind-altering effects. Today, the Chinese still mostly depend on traditional medicines, with over 5000 plants and plant products in their pharmacopeia [14]. In the United States, the development of drugs based on natural products also has a long history. Although some traditional remedies are still used, their usage as a proportion is very small in comparison with modern medications, particularly for treatment of currently emerging diseases [15].

Accordingly, we can say that natural products provided important clues in drug discovery and are therefore considered to be the cornerstone of drug development [16]. Actually, many drugs in the market today were discovered from natural sources. For example, morphine, isolated from opium, was produced and commercialized in 1826. It was developed as the first drug with ensured purity and is still clinically used [17].

Nature provides us with a huge range of structurally diverse secondary metabolites. These structural diversities reflect a variety of biological antitumor agents that include, for example, inhibitors of enzymes and antitumor agents [18]. Bioactive products, such as antibiotics and antitumor and immunosuppressive agents, are clinically important. In addition, growth promotors, insecticides, herbicides, and antiparasitics are important for veterinary and agricultural applications [19].

Over 300,000 natural products exist, and they can be classified according to their chemical nature into five categories: terpenoids and steroids, fatty-acid-derived substances and polyketides, alkaloids, nonribosomal polypeptides, and shikimate-derived compounds [19]. These compounds exhibit different bioactivities, such as antibacterial, antifungal, and antialgal activities, with different mechanisms for killing pathogens. More than 10,000 of these compounds are biologically active, and more than 8000 are antibiotic and antitumor agents [20].

\subsection{Distribution of Natural Products}

As previously mentioned, natural products can be produced by almost all types of living cells (plants, animals, and microorganisms), although their production is not similar at all levels. However, they represent valuable resources of many and diverse natural products, the so-called "natural sources deriving compounds". This biodiversity provides an unlimited source of novel chemical entities (NCE) or secondary metabolites with potential bioactivities [21].

Moreover, it is well known that oceans cover about 70\% of the Earth's surface, highlighting, in general, the importance of marine sources in the biodiscovery of drugs. The marine world contains a huge variety of ecosystems covering a wide range of conditions, such as temperatures, nutrients, and lighted/unlighted zones. This variety confers suitable conditions for the proliferation of a wide range of organisms, such as invertebrates including sponges, coelenterates (sea whips, sea fans, and soft corals), 
ascidians (also called tunicates), opisthobranches mollusks (nudibranchs, sea hares, etc.), echinoderms (starfish, sea cucumbers, etc.), and bryozoans (marine algae including green algae, brown algae, red algae, golden algae, and diatoms) as well as marine microorganisms (bacteria and fungi) [22].

Thousands of novel secondary metabolites with a vast diversity of uniquely sophisticated chemical entities have been isolated from marine organisms, especially invertebrates, proving that marine organisms are a rich source of new structural classes of secondary metabolites. Some of the most promising organisms for the discovery of new drugs are expected to be marine invertebrates and microorganisms [23]. The exploration of many marine organisms, such as sponges, soft corals, algae, ascidians, bryozoans, and mollusks, has produced unique secondary metabolites that exhibit structural/chemical features not found in terrestrial natural products [24].

Amongst all the marine invertebrates, sponges represent the most described group with potential application in medicinal chemistry, representing a valid starting point for new drug leads due to their chemical defense mechanisms [25]. Sponges are the most primitive multicellular invertebrates and have played an important role in the past 50 years, with many promising bioactive compounds isolated from them [26], although only few compounds have been commercialized. Thus, a deep insight into the chemical ecology of bioactive metabolites is desirable. The number of products isolated from sponges and their related microorganisms exceeds 5000, and more than 200 novel compounds are annually reported [27].

Over 1000 new bioactive compounds isolated from sponges were reported in 2009. Sponges serve as hosts to different symbiotic/parasitic organisms, including blue-green algae and bacteria. However, these metabolites are suggested to be produced by symbiotic microorganisms. The close similarities between natural products from some classes of sponge and some terrestrial microorganisms support this assumption [28].

Sponges alone produce more than 3300 antibiotics and other bioactive compounds. However, the active compounds isolated from these animals have proven to mostly originate from microorganisms that live symbiotically with them. Only a very few compounds with antibacterial activity have been isolated from animal microbes (protozoa, ciliates). Bioactivities have been found to be rare in compounds isolated from crustaceans, arachnids, fish, and birds [21,29].

Lichens and lower plants, such as the Bryophyta species, have produced hundreds of bioactive compounds. Higher green plants (Spermatophyta), gymnosperms, and angiosperms produce structurally unique secondary metabolites, including alkaloids, flavonoids, and terpenoids, exhibiting antimicrobial and/or antitumor activities [30,31].

Despite all the aforementioned valuable resources for drug discovery, we are still in need for exploration of new, unique, and unlimited sources to combat and overcome currently emerging diseases. Moreover, the increased emergence of antibiotic-resistant pathogens is the biggest threat to public health worldwide, which necessitates search for other unexplored sources of novel, effective drugs to combat such resistance. The most promising source is microorganisms [30].

The most versatile producers are the microbial producers (prokaryotes and eukaryotes). In prokaryotes, unicellular bacteria, namely, the Bacillus and Pseudomonas species, filamentous actinomycetes, myxobacteria, and cyanobacteria, are the most frequent producers [32]. Species of the order Actinomycetales produce over 10,000 bioactive compounds- 7600 derived from Streptomyces and 2500 from the so-called rare actinomycetes species-representing the largest group (45\%) of bioactive microbial metabolites. On the other hand, eukaryotic fungi, especially endophytic fungal species, are the most significant producers, while yeasts, phycomycetes, and slime molds rarely produce bioactive metabolites. The total number of bioactive metabolites produced by fungal species is approximately 8600 , representing $38 \%$ of all microbial products $[33,34]$.

\section{Microbial Sources in Drug Discovery}

Microorganisms play an important role in the development of the chemistry of natural products and medical therapy. They have been considered to be a rich source of unique bioactive compounds 
since the discovery of penicillin (Figure 1) in 1929 [34], which was structurally elucidated in 1945 and introduced as the first antibiotic by Fleming, Chain, and Florey [35].

(a)

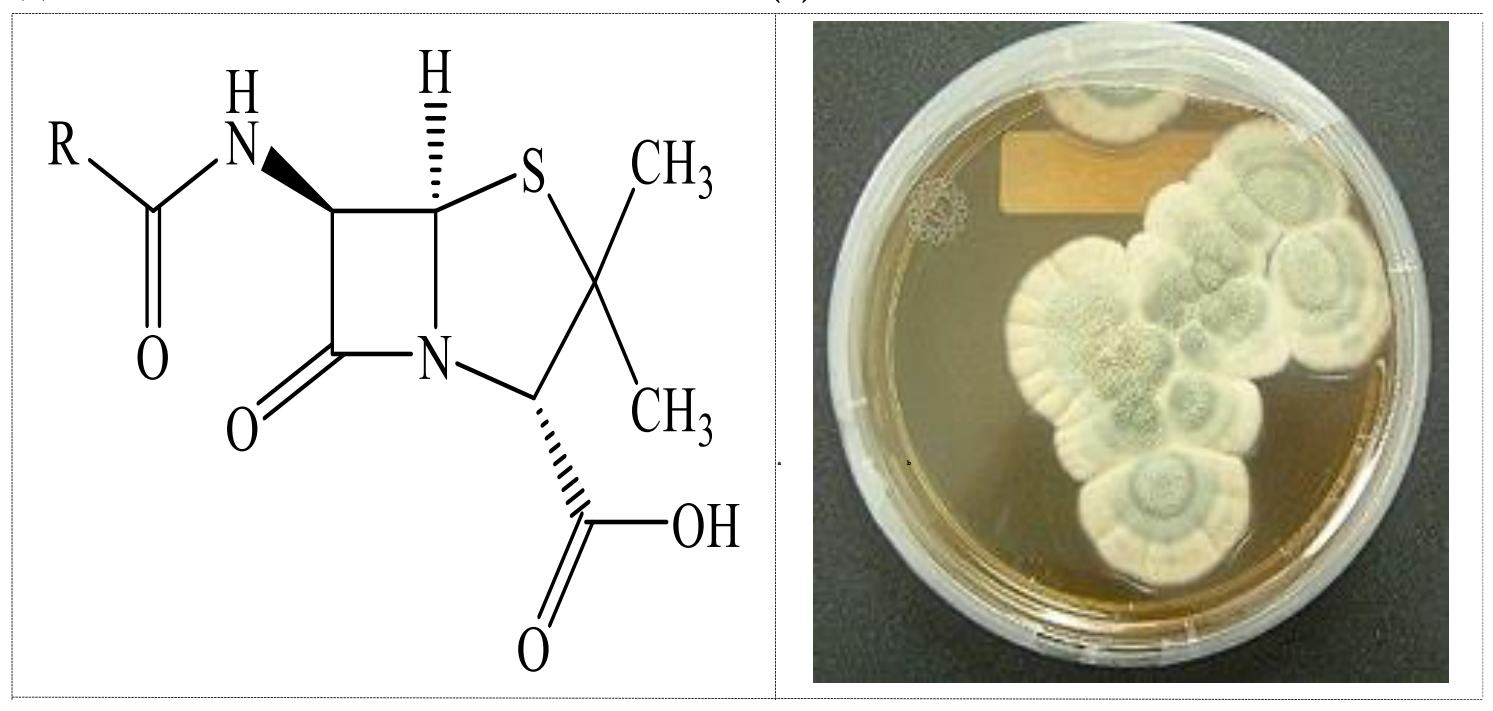

Figure 1. (a) Core structure of penicillin, the first antibiotic from fungus; (b) Penicillium notatum.

Today, many microbial-originated antibiotics are available in the market, and more than 120 of the most important medicines in use are obtained from terrestrial microorganisms [36]. A large number of bioactive metabolites are used in medicine, agriculture, and industry, but about 100 of them are used for therapeutic purposes, herbicidal activity, growth-promoting agents, or tools for biochemistry [37].

Recently, there has been great interest in natural products from unexplored microbial sources, especially actinomycetes [38], marine ecosystems [39], and microorganisms associated with plants [40], mammals [41], and invertebrates [42] from marine and terrestrial habitats. Despite the most important antibiotics currently in use being derived from cultivable microorganisms, only a tiny fraction of microorganisms can be cultivated in routine lab cultures [43]. The majority of microorganisms in biosamples cannot be cultivated under normal laboratory conditions and are called uncultivated microorganisms. This kind of microorganisms can be cultivated using systems developed specifically for the organisms, such as synthetic medium mimicking the biosystem conditions and several other in situ cultivation strategies [44].

\subsection{Natural Products from Fungal Sources}

Fungi are distributed in nature, and these eukaryotic, heterotrophic microorganisms often live symbiotically. Fungi have been used for a long time by humankind for many purposes, including food production (beer, wine, leavened bread, soy foods), treatments, and in everyday life. Thousands of years ago, fungi were used to treat intestinal diseases by the Mayans. Since the discovery of penicillin, which was isolated from the fungus Penicillium notatum, fungi have been a rich source of many therapeutic agents [45]. Fungi are a rich source of biologically active secondary metabolites (Figure 2). 


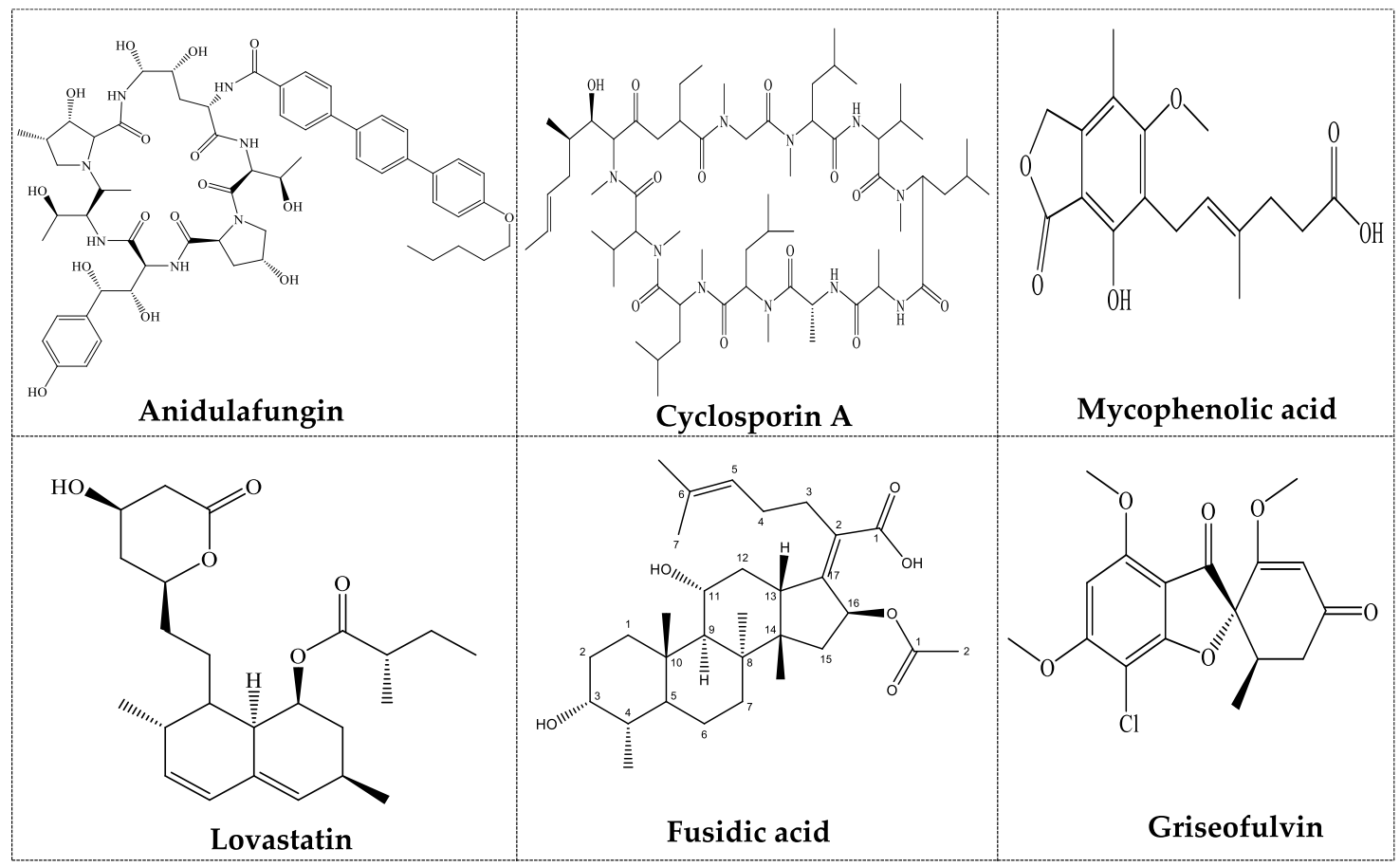

Figure 2. Some medically important natural compounds from fungi.

Many therapeutic agents, such as cyclosporine and mycophenolic acid (immunosuppressive activity), fusidic acid and griseofulvin (antimicrobial activity), and other novel semisynthetic antifungal drugs, such as anidulafungin and caspafungin, have been derived from fungal metabolites [45]. Recently, cyclosporine was used to develop Debio 025, which was clinically proven to have potent antiviral activity [46].

One of the most important drugs are statins, including mevastatin from Penicillium citrinum [47] and lovastatin from Aspergillus terreus [48]. Statins, an important class of antilipidemic drugs for the treatment of cardiovascular diseases [49], are also derived from microbial sources. Fungal metabolites are not only important for medicine but also for plant protection. For instance, the discovery of strobilurins, which were first isolated from Strobilurus species, led to compounds for synthetic fungicides, such as trifloxystrobin [50].

Plant endophytes have been defined in several ways. The most common definition is "all organisms inhabiting plant organs that at some time in their life can colonize internal plant tissues without causing apparent harm to the host" [51]. Fungi are more frequently observed as endophytes than bacteria [52]. An endophytic fungus is a fungus that can colonize healthy tissues of the host plant, typically causing no apparent symptoms of disease. There are symbiotic relationships between the host plants and their endophytes by which the host can support and provide nutrients to the fungus and later produce metabolites that are important to the host. This symbiotic relationship may be suddenly reversed to opportunistic if the host plant is weakened [52].

Endophytes are a polyphyletic group of primarily ascomycetous fungi, whereas basidiomycetes, deuteromycetes, and oomycetes rarely exist [53]. There is no host specificity, but it has been noticed that some families frequently colonize certain hosts. The great diversity and ecological roles of endophytes produce a variety of pharmaceutically and agrochemically promising secondary metabolites [54,55].

About 140 new bioactive compounds were isolated from endophytic fungi in the period between 1987 and 2000. Between 2000 and 2006, a similar number of compounds were isolated [56]. The ability to produce pharmacologically important natural products is not only restricted to plant sources but is also inherent to associated endophytes $[57,58]$. Amongst the isolated products, cryptocin, from the endophytic fungus Cryptosporiopsis quercina, an endophyte of Tripterigeum wilfordii, has shown potent activity against the world's worst plant pest, Pyricularia oryzae, and other plant pathogenic fungi [57]. 
Phomol, an active polyketide lactone that is isolated from the endophyte Phomopsis sp., an endophyte of the medicinal plant Erythrina crista-galli, exhibits anti-inflammatory as well as antimicrobial activity [59]. Some of the US Food and Drug Administration (FDA)-approved drugs from fungi are presented in Table 1.

Several endophytic fungi can produce secondary metabolites that are also biosynthesized by their host plants (Figure 3) [60]. These include, for example, antineoplastic paclitaxel [61], camptothecin and its structural analogues [62], the anticancer drug lead compounds podophyllotoxin [63] and deoxypodophyllotoxin [64], the antidepressant hypericin along with emodin [65], and the natural insecticides azadirachtin A and B [55].

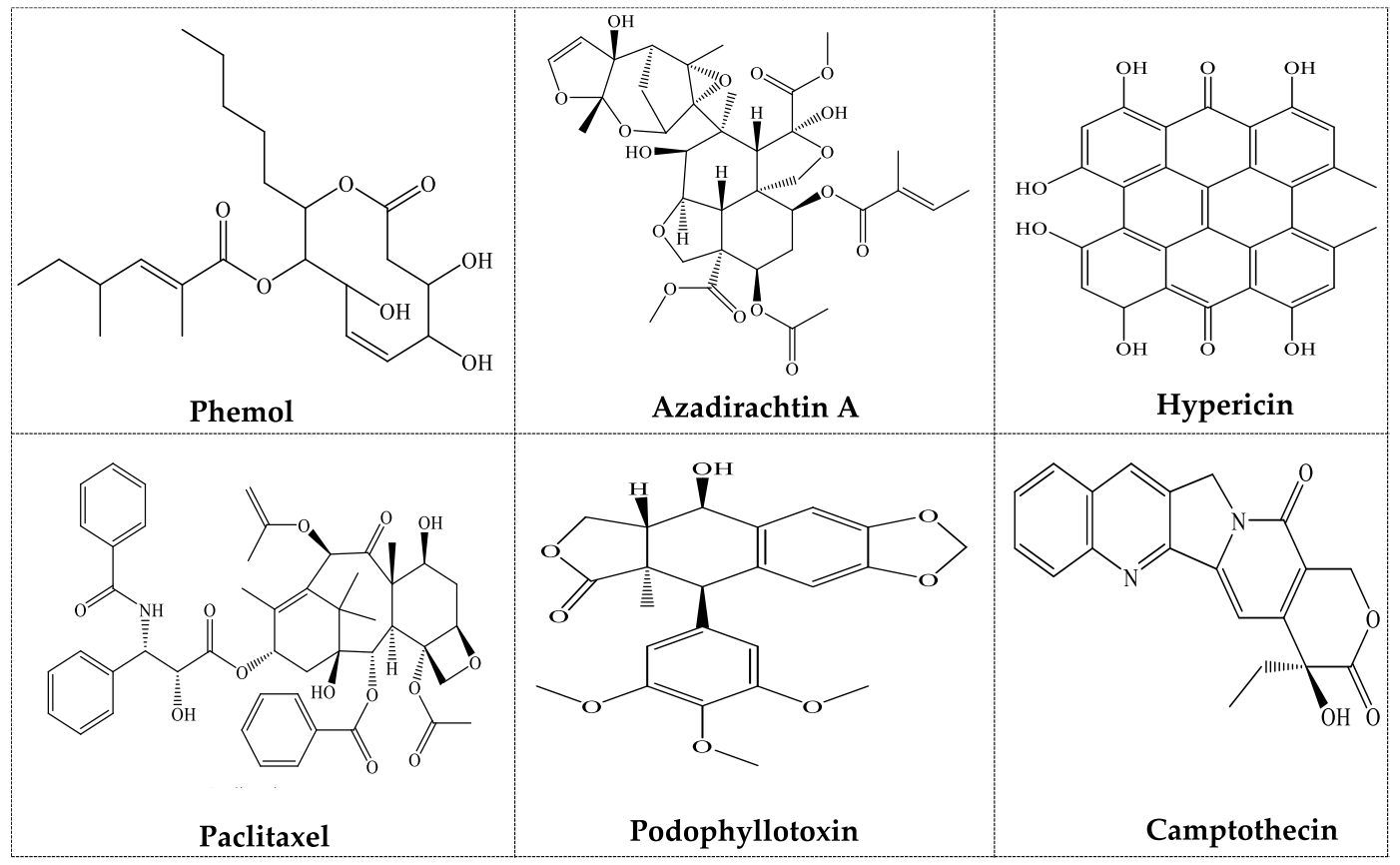

Figure 3. Some important bioactive compounds from endophytic fungi.

Table 1. Some US Food and Drug Administration (FDA)-approved drugs from fungi.

\begin{tabular}{|c|c|c|c|c|}
\hline Compound & Derived Product & Producing Fungus & Application & Reference \\
\hline Compactin & Mevastatin & Penicillium compactum & $\begin{array}{c}\text { Cholesterol-lowering } \\
\text { agent }\end{array}$ & [66] \\
\hline Mevacor & Lovastatin & Aspergillus terreus & $\begin{array}{c}\text { Cholesterol-lowering } \\
\text { agent }\end{array}$ & [48] \\
\hline Pravastatin & Pravachol & $\begin{array}{l}\text { Penicillium compactum } \\
\text { Aspergillus spp., } \\
\text { Monascus spp. }\end{array}$ & $\begin{array}{l}\text { Cholesterol-lowering } \\
\text { agent; Antithrombotic } \\
\text { and anti-inflammatory } \\
\text { agents }\end{array}$ & {$[3,9]$} \\
\hline Compactin & ML-236B & $\begin{array}{c}\text { Penicillium } \\
\text { brevicompactum }\end{array}$ & Antifungal activity & [2] \\
\hline Caspofungin & Cancidas & Glarea lozoyensis & Fungal infections & [18] \\
\hline Anidulafungin & Anidulafungin & Aspergillus nidulans & Fungicidal & [10] \\
\hline Strobilurins & Strobilurins & Stobilurus tenacellus & Agricultural fungicides & {$[22,50]$} \\
\hline Taxol & Paclitaxol & Sporangium cellulosum & $\begin{array}{l}\text { Antitumor and } \\
\text { antifungal activity }\end{array}$ & {$[11,12]$} \\
\hline
\end{tabular}


Table 1. Cont.

\begin{tabular}{|c|c|c|c|c|}
\hline Compound & Derived Product & Producing Fungus & Application & Reference \\
\hline Cryptocin & Cryptocin & $\begin{array}{l}\text { Cryptosporiopsis } \\
\text { quercina }\end{array}$ & Pesticide & [57] \\
\hline Phomol & Phomol & Phomopsis sp. & $\begin{array}{l}\text { Anti-inflammatory and } \\
\text { antimicrobial activities }\end{array}$ & [59] \\
\hline Penicillins & Penicillins & Penicillium notatum & Bacterial infections & [13] \\
\hline Cephalosporins & Cephalosporins & Cephalosporium & Bacterial infections & [14] \\
\hline Fusidic Acid & Fucidin & Fusidium coccineum & Bacterial infections & [15] \\
\hline Cyclosporin A & Cyclosporin A & Tolypocladium inflatum & $\begin{array}{l}\text { Immunosuppressive } \\
\text { agent in organ } \\
\text { transplantation }\end{array}$ & [16] \\
\hline Mycophenolic Acid & Myfortic, CellCept & Penicillium stoloniferum & $\begin{array}{l}\text { Immunosuppressive } \\
\text { agent in organ } \\
\text { transplantation }\end{array}$ & [17] \\
\hline Fingolimod & Gilenya & Isaria sinclairii & Multiple sclerosis & {$[19,67]$} \\
\hline Ergot & Ergotamine & Claviceps purpurea & Migraine headaches & {$[20,21]$} \\
\hline
\end{tabular}

\subsection{Natural Products from Bacterial Sources}

Nearly three-quarters of microbial-produced bioactive compounds are from actinomycete bacteria. Streptomycetes are the most widely identified group, producing a wide range of biologically active compounds. They are Gram-positive aerobic filamentous (often soil) bacteria [68]. Euzeby (2008) [69] described more than 500 species of streptomycetes. They mostly produce spores and are characterized by the production of geosmin, a volatile metabolite that give them "earthy" odor. The spore germination process depends on the environmental conditions. In normal conditions, the germination of streptomycete spores starts by arthrospore (substrate mycelium), but in the case of nutrient depletion, the growth starts with aerial mycelium. In other words, under favorable conditions, a fully matured mycelia is produced. Under drastic conditions, on the other hand, the aerial mycelium is subdivided by septa, then into spores, which in turn can, under certain conditions, germinate into mycelium [70].

Actinomycetes are known to produce various types of antibiotics, namely, peptides/glycopeptides [71], angucyclinone [72], tetracyclines [73], phenazines [74], macrolides [75], anthraquinones [76], polyenes [77], anthracyclines [78], beta-lactams [79], piercidins [80], octaketides [81], benzoxazolophenanthridines [82], heptadecaglycosides [83], and lactones [84].

The production of secondary metabolites in actinomycetes is greatly affected by various fermentation parameters, such as nutrients availability, $\mathrm{pH}$, aeration, temperature, mineral salts, heavy metals, precursors, inducers, and inhibitors, which often vary from organism to organism $[85,86]$.

Streptomycetes are good soil inhabitants and are considered to be valuable sources of many enzymes, such as lipases and cellulases [87]. In addition, some genes from these bacteria may be applied to plants to produce genetically modified plants with improved characteristics [88]. The genes for the production of secondary metabolites are considered to be nonessential and are often found near the ends of linear chromosomes; the chromosomes of streptomycetes, in general, are linear [89].

Streptomycetes are a rich source of many bioactive compounds. Most antifungals derived from streptomycetes tend to be macrolide polyene, such as nystatin, produced by streptomyces. noursei [90]; amphotericin B, produced from streptomyces nodosus, and natamycin, produced by streptomyces natalensis [91]. A huge number of streptomyces-derived antibiotics are used as antibacterial agents. Starting with aminoglycosides, a large number show antibacterial activity, such as streptomycin, produced by streptomyces griseus [92]; neomycin, produced by streptomyces fradiae [93]; and kanamycin, produced by streptomyces kanamyceticus [94]. Other antibacterial antibiotics from streptomycetes include erythromycin, produced by streptomyces erythraea; tetracycline produced by streptomyces rimosus [95]; chloramphenicol produced by streptomyces venezuelae [96]; vancomycin, produced by streptomyces orientalis; and thienamycin, produced by Streptomyces cattleya [97]. Some chemical alterations could be useful for producing novel structures with new properties in so-called "semisynthetic drugs" [91]. 
Tigecycline, a derivative of minocycline, is semisynthesized from chlortetracycline (produced by streptomyces aureofaciens) and exhibits antibacterial activity [98]. Everolimus, a derivative of rapamycin (produced by streptomyces hygroscopicus), exhibits an immunosuppressive activity [99]. Another example, brostallicin, a derivative of distamycin A (isolated from streptomyces distallicus), exhibits anticancer activity [100].

About two-thirds of bioactive compounds are produced by this group, and they have many clinical efficacies against different kinds of organisms, such as bacteria, fungi, and parasites. In addition, other drugs in this category exhibit antitumor activities, such as aclacinomycin A, actinomycin D, bleomycin, daunorubicin, mithramycin, mitomycin C, and nogalamycin (produced by Streptomyces glalilaeus, Streptomyces antibioticus, Streptoverticillium verticillium, Streptomyces paecetius, Streptomyces argillaceus, Streptomyces lavendulae, and Streptomyces nogalater, respectively) [101]. These drugs can act on DNA by altering its function via different mechanisms, such as intercalation, cross-linking, DNA strand breakage, or interacting with DNA non-intercalatively [102]. Approximately $3 \%$ of all antibacterial have been synthesized by streptomycetes [103], which serves as a promising source for discovering novel drugs.

Accordingly, actinobacteria have played a significant role in human health in the last decades throughout the world. Like fungi, there are many actinobacteria that can be associated with and colonize the inner tissues of higher plants but do not visibly harm the plants. These are called endophytic actinobacteria and represent an important source of many bioactive compounds. These microbes inhabit different plant organs inter- and intracellularly. It is worth mentioning that there are about 300,000 plant species on Earth and that each individual plant is considered to host one or more type of endophytes, creating huge biodiversity of compounds and functions [104]. Endophytic actinobacteria associated with traditionally used medicinal plants, especially of the tropics, could be a rich source of promising compounds. Many endophytic actinobacteria, especially those from medicinal plants, possess the ability to inhibit or kill a wide variety of harmful microorganisms like pathogenic bacteria, fungi, and viruses [44].

The most promising value of endophytes is to produce many new antitumor and anti-inflammatory agents. Considering that endophytic actinobacteria are closely associated with their host plant, it is possible for horizontal gene transfer (HGT) to occur, resulting in the production of plant-derived compounds by a microbe, such as the paclitaxel-producing Kitasatospora sp. isolated from Taxus baccata in Italy [105]. Maytansinoids are extraordinarily potent antitumor agents that were originally isolated from members of the higher plant families Celastraceae, Rhamnaceae, and Euphorbiaceae [106,107] as well as some mosses [108] and, remarkably, from plant-associated actinomycete Actino-synnema pretiosum [109].

Recently, two compounds, 5, 7-dimethoxy-4-phenylcoumarin and 5, 7-dimethoxy-4-p-methoxylphenyl coumarin, originally produced by numerous species of plants, were isolated from endophytic Streptomyces aureofaciens CMUAc130 and were shown to have antifungal and antitumor activity [110]. Endophytic actinobacteria also produce other bioactive compounds with different functions, such as the antimalarial coronamycin, isolated from Streptomyces sp. (MSU-2110), an endophyte of Monstera sp. Recently, endophytic actinobacteria have been used to produce some biological control agents in order to protect plants against different soilborne plant pathogens, including Rhizoctonia solani, Verticillium dahliae, Plectosporium tabacinum, Gaeumannomyces graminis var. tritici, Fusarium oxysporum, Pythium aphanidermatum, and Colletotrichum orbiculare [111,112].

Endophytic actinobacteria have sparked great interest because they possess many properties that could be beneficial for plant growth. For example, several endophytic actinobacteria isolated from winter rye produced indolyl-3-acetic acid, which enhanced seedling germination [113]. In most cases, natural compounds from bacteria need some modifications to optimize their properties. These alterations may be controlled during synthesis by metabolic engineering or by changing synthesis technology, as studied in several bacteria [114]. Such methods may produce novel compounds by expressing a newly identified pathway or using gene combination to create a new synthetic pathway. 
However, the enzymes involved in biosynthetic pathway are like fatty acid synthases, which are conserved in eukaryotes and prokaryotes [115].

Due to the drug-resistance phenomena, new approaches have been employed to find new drugs from microorganisms by studying well-known productive strains, developing new screening methods [116], carrying out chemical modifications of biosynthesized precursors and combinatorial biosynthesis [117], and doing intensive studies to select and discover new strains from new sources. Thus, much effort has to be made to compensate for the emerging resistance as no novel compounds have been discovered during the period between the introduction of quinolone nalidixic acid (1962) and linezolid (2000) [118].

One of the factors that enhanced the resistance problem is the use of about $50 \%$ of existing antimicrobials for purposes other than therapeutic use [119], such as food additives in livestock breeding. The study of metabolic pathways and the genetics of microbes are beneficial in production strategies and in regulatory mechanisms employed by the productive strain, such as in the Streptomyces coelicolor [120] and Streptomyces avirmitilis genome projects [121].

Recently, marine actinomycetes have been considered to be a promising and unique resource for novel bioactive secondary metabolites [122] because environmental conditions of the sea are extremely different from terrestrial conditions and they are widely distributed within the marine ecosystem and found in intertidal zones, seawater, animals, plants, sponges, and in ocean sediments [123-125].

In addition, these actinomycetes have the ability to form stable populations in different habitats and produce many compounds with various activities [126]. This explains the importance of this group as a source of novel compounds. Many novel pharmaceutically important compounds have been produced from marine actinomycetes, such as the anticancer salinosporamide $\mathrm{A}$, which is produced by Salinispora tropica [127]; salinipyrones A and B, produced by Salinispora pacifica [128]; iodopyridone, produced by marine Saccharomonospora sp. [128]; and srenimycin, produced by Salinispora arenicola [129] (Figure 4). Table 2 lists some of FDA-approved drugs from actinomycetes.

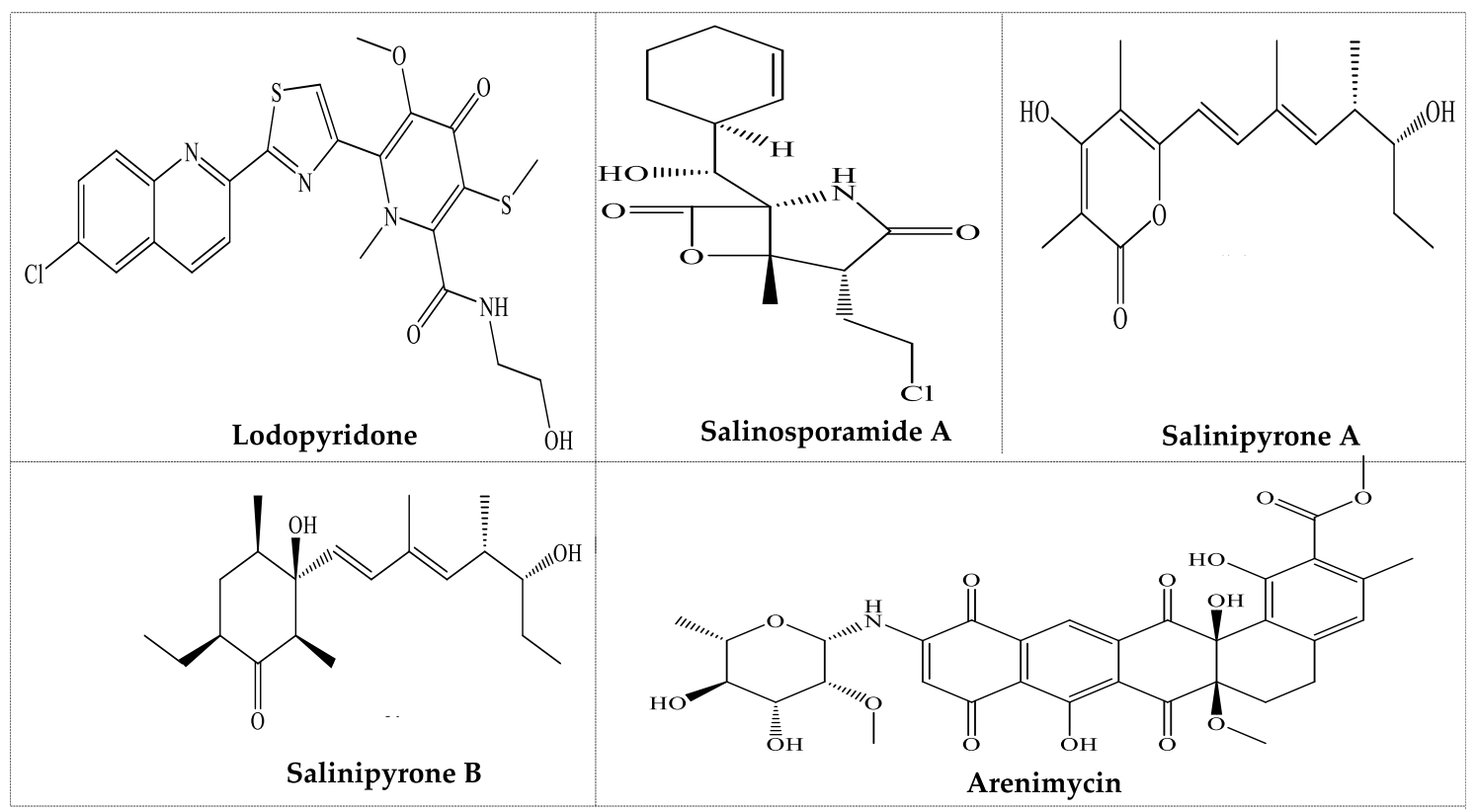

Figure 4. Some novel natural compounds produced by marine actinomycetes. 
Table 2. Some FDA-approved drugs from bacteria.

\begin{tabular}{cccc}
\hline Compound & Producing Bacteria & Application & Reference \\
\hline Tigecycline & Streptomyces aureofaciens & Antibacterial for & {$[98]$} \\
Telithromycin & Saccharopolyspora erythraea & tetracycline-resistant organisms & {$[130]$} \\
Biapenem and & Antibacterial activity & {$[131,132]$} \\
Ertapenem & Streptomyces cattleya & Antibacterial activity & {$[99]$} \\
Everolimus & Streptomyces hygroscopicus & Immunosuppresive agent & {$[133]$} \\
Miglustat & Streptomyces roseosporus & Type 1 Gaucher disease & {$[134]$} \\
Daptomycin & Streptomyces peuceticus & Antitumor activity & {$[135]$} \\
Amrubicin & Streptomyces hygroscopicus var & Anti-inflammatory for skin disease & {$[135]$} \\
Pimecrolimus & ascomyceticus & & \\
Gemtuzumab & Micromonospora echinospora sp. & Acute myeloid lymphoma treatment & {$[136]$} \\
ozogamicin & calichensis & &
\end{tabular}

\subsection{Natural Products from Algae}

Algae are a prolific source in natural product chemistry and include prokaryotic (cyanobacteria) and eukaryotic species. They are represented by approximately 30,000 species that have a function of supplying oxygen to the biosphere [137]. They are also a very good nutritional source for fish and humans. Moreover, they can be used in medicine and fertilizers. The most important group of compounds produced by algae are terpenoids, which comprise many classes, including brominated derivatives, phenazine derivatives, oxygen and nitrogen heterocycles, amino acids, and guanidine derivatives [138].

Investigation of natural products from algae started in 1970 [139]. Among the important compounds produced by algae are polycavernoside A from the red alga Polycaverosa tsudai [128]; antitumor active 4-acetoxydictylolactone, dictyolide A, B (diterpenes), and nordictyolide from the brown alga, Dictyota dichotoma [140]; and antimicrobially active crenuladial, which is isolated from the brown alga Dilophus ligatus [141] (Figure 5). However, red algae, especially the genus Laurencia (Rhodophyta), commonly produce halogenated sesquiterpenes and diterpenes [142]. It is worth mentioning that algae are a very extensive source of new insecticides and have replaced chemically resistant synthesized pesticides [143]. Examples of potent insecticides from algae include ( $Z$ )-laureatin, laurepinnacin, and $1 \beta$-(2-E-chlorovinyl)-2 $\beta, 4 \alpha, 5 \alpha$-trichloro- $1 \alpha, 5 \beta$-dimethylcyclohexane and its enantiomer [144].

\subsection{Natural Products from Microbial Community Interactions}

Among the many recent approaches for the discovery of new drugs is cocultivation (mixed cultures), by which we can cultivate together two or more organisms from different species, mimicking the natural microbial community interactions. Recent investigations have indicated that microbial interactions induce the production of new specialized metabolites through the activation of some cryptic genes, providing a very promising tool for drug discovery $[145,146]$.

Two new compounds, namely, fumiformamide and N,N'-((1Z,3Z)-1,4-bis(4-methoxyphenyl)buta1,3-diene-2,3-diyl) diformamide, have been isolated from the mixed culture of Aspergillus fumigatus with Streptomyces peucetius [147]. Many other new bioactive compounds have been isolated via bacterial-fungal cocultivation, such as potent bactericidal pestalones [148], potent cytotoxic libertellenones D [149], antimicrobially active emericellamides A [150], and anti-tumor glionitrin A [151].

Several novel compounds, namely, arcyriaflavin E [147], chojalactones A-C, niizalactams A-C [151], and 5-alkyl-1,2,3,4-tetrahydroquinolines, have been isolated from cocultures of Streptomyces spp. with Tsukamurella pulmonis. Moreover, the new keyicin which is anthracyclic antibiotic active against some Gram-positive bacteria, is isolated from coculturing of two bacterial strains, Micromonospora sp. with Rhodococcus sp. [152]. All these findings indicate that the cocultivation strategy is a very promising tool in drug discovery from microorganisms. 


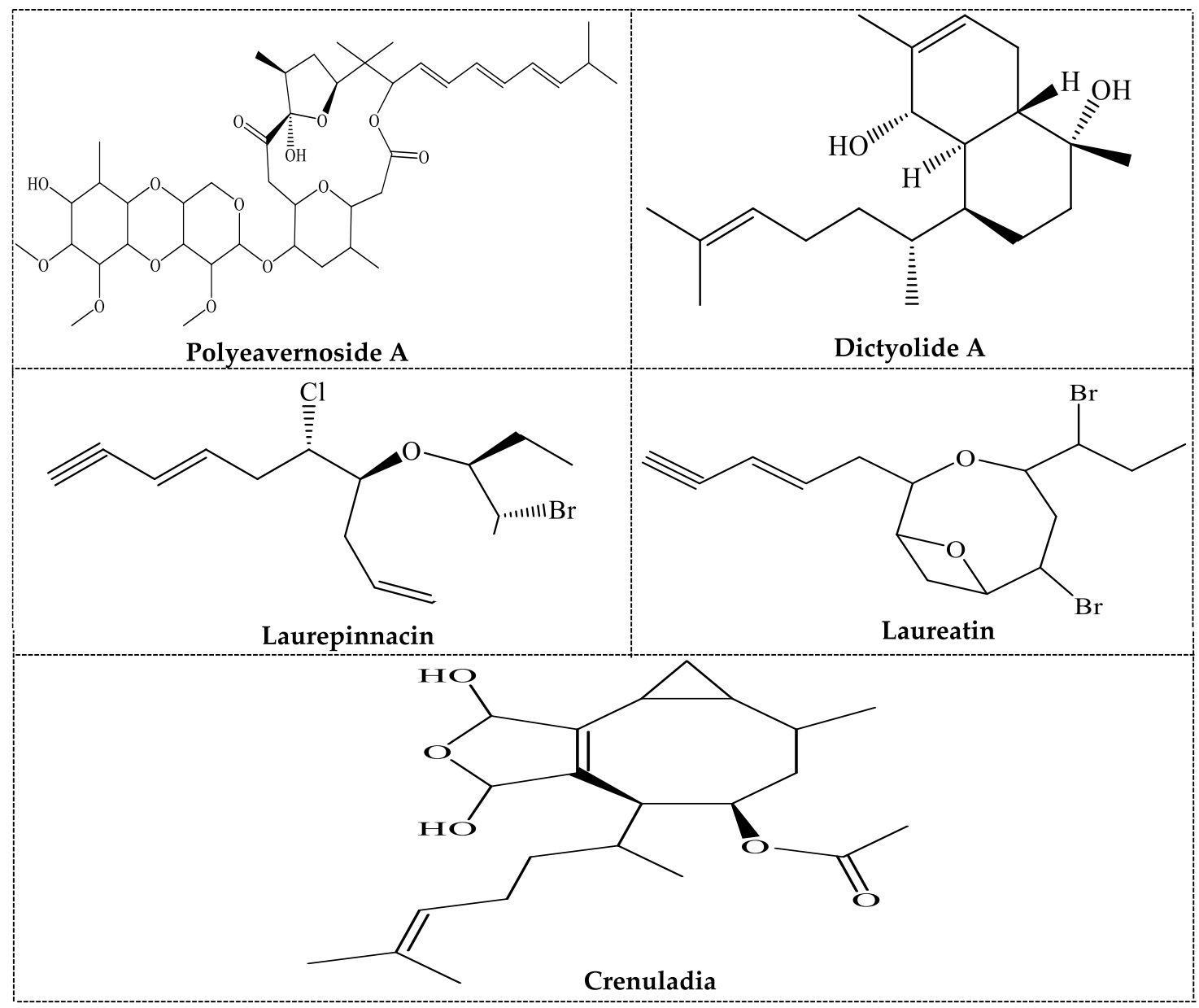

Figure 5. Some novel bioactive compounds from marine algae.

\section{Conclusions}

In summary, natural products play a significant role in human life. Microbial natural products are the most versatile and are of interest because of their unique structures and functions, due to which they are considered the cornerstone of drug discovery. Despite the use of microorganisms as a source of drugs being a recent discovery, the most important and commercially available antibiotics and many other anti-infectives are obtained from them. Recent research initiatives have been directed toward endophytic microorganisms due to their importance as a source of novel compounds.

Furthermore, marine macro- and microorganisms provide endless resources for novel bioactive compounds as they cover about $70 \%$ of the Earth's area. Even marine macroorganisms (plants and animals) are interesting sources of novel bioactive compounds, mostly due to their inhabitant microbiota, which are often responsible for the production of their secondary metabolites. However, only a small number of microorganisms can be used for defense mechanisms of their hosts (plants and animals) and for other ecological interactions within their microbiota, such as commensalism and symbiosis, which produce very useful products for them and their hosts. Because only a small number of microorganisms can be cultivated under laboratory conditions, more of such systems need to be developed using in situ cultivation strategies.

One of the most recent approaches in drug discovery from microorganisms is cocultivation. In the cocultivation strategy, we can cultivate two or more organism from different species. Through this, their physiology can be changed to produce cryptic compounds that cannot otherwise be produced in routine cultivation media. 
Overall, the present review highlighted the role of biodiversity in providing a vital link for expanding the molecular diversity needed for successful drug discovery attempts in the future, with microbial inhabitants being a unique source of bioactive secondary metabolites and their therapeutic applications. This review therefore attempted to place emphasis on many important concepts in the field of microbial natural products that use cost-effective techniques utilizing recent cultivation ideas mimicking the natural ecological conditions where microorganisms always co-exist within complex microbial communities, such as cocultivation and in situ cultivation. We will further discuss the recombinant DNA technology and other probable molecular tools in future studies to address the most applicable approaches.

Author Contributions: Conceptualization, A.S.A.-R. and M.E.E.-N.; methodology, A.S.A.-R., A.A. and O.M.M.; validation, A.S.A.-R. and S.I.O., writing—review and editing, A.S.A.-R., M.E.E.-N., O.M.M., A.A. and S.I.O. All authors have read and agreed to the published version of the manuscript.

Acknowledgments: This research was funded by the Deanship of Scientific Research at Princess Nourah bint Abdulrahman University through the Fast-track Research Funding Program.

Conflicts of Interest: The authors declare no conflict of interest.

\section{References}

1. Ebada, S.S.; Edrada, R.A.; Lin, W.; Proksch, P. Methods for isolation, purification and structural elucidation of bioactive secondary metabolites from marine invertebrates. Nat. Protoc. 2008, 3, 1820. [CrossRef] [PubMed]

2. Baker, W.; van den Broek, A.; Camon, E.; Hingamp, P.; Sterk, P.; Stoesser, G.; Tuli, M.A. The EMBL nucleotide sequence database. Nucleic Acids Res. 2000, 28, 19-23. [CrossRef] [PubMed]

3. Shen, B. A new golden age of natural products drug discovery. Cell 2015, 163, 1297-1300. [CrossRef] [PubMed]

4. El-Naggar, M.E.; Soliman, R.A.; Morsy, O.M.; Abdel-Aziz, M.S. Nanoemulsion of Capsicum fruit extract as an eco-friendly antimicrobial agent for production of medical bandages. Biocatal. Agric. Biotechnol. 2020, 23, 101516. [CrossRef]

5. $\quad$ El-Sayed, S.M.; El-Naggar, M.E.; Hussein, J.; Medhat, D.; El-Banna, M. Effect of Ficus carica L. leaves extract loaded gold nanoparticles against cisplatin-induced acute kidney injury. Colloids Surf. B Biointerfaces 2019, 184, 110465. [CrossRef]

6. Sharaf, S.; El-Naggar, M.E. Wound dressing properties of cationized cotton fabric treated with carrageenan/cyclodextrin hydrogel loaded with honey bee propolis extract. Int. J. Biol. Macromol. 2019, 133, 583-591. [CrossRef]

7. Sharaf, S.; El-Naggar, M.E. Eco-friendly technology for preparation, characterization and promotion of honey bee propolis extract loaded cellulose acetate nanofibers in medical domains. Cellulose 2018, 25, 5195-5204. [CrossRef]

8. Hussein, R.A.; Salama, A.A.A.; El Naggar, M.E.; Ali, G.H. Medicinal impact of microalgae collected from high rate algal ponds; phytochemical and pharmacological studies of microalgae and its application in medicated bandages. Biocatal. Agric. Biotechnol. 2019, 20, 101237. [CrossRef]

9. Busia, K.; Kasilo, O.M.J. Overview of traditional medicine in ECOWAS member states. Afr. Heal. Monit. WHO AFRO 2010, 13, 16-24.

10. Barton, D. Comprehensive Natural Products Chemistry; Newnes: Burlington, MA, USA, 1999; ISBN 0080912834.

11. Newman, D.J.; Cragg, G.M.; Snader, K.M. The influence of natural products upon drug discovery. Nat. Prod. Rep. 2000, 17, 215-234. [CrossRef]

12. Zhong, G.; Wan, F. An outline on the early pharmaceutical development before Galen. Chin. J. Med. Hist. $1999,29,178-182$.

13. Cheng, Z.F.; Zhen, C. The Cheng Zhi-Fan Collectanea of Medical History; Peking Univ. Med. Press: Beijing, China, 2004.

14. Petrovska, B.B. Historical review of medicinal plants' usage. Pharmacogn. Rev. 2012, 6, 1. [CrossRef]

15. Patwardhan, B.; Mashelkar, R.A. Traditional medicine-inspired approaches to drug discovery: Can Ayurveda show the way forward? Drug Discov. Today 2009, 14, 804-811. [CrossRef] 
16. Newman, D.J.; Cragg, G.M. Natural products as sources of new drugs over the 30 years from 1981 to 2010. J. Nat. Prod. 2012, 75, 311-335. [CrossRef]

17. Courtwright, D.T. Forces of Habit: Drugs and the Making of the Modern World; Harvard University Press: Cambridge, MA, USA, 2009; ISBN 0674029909.

18. Carmichael, W.W. Cyanobacteria secondary metabolites-The cyanotoxins. J. Appl. Bacteriol. 1992, 72, 445-459. [CrossRef] [PubMed]

19. Méndez, C.; Salas, J.A. Altering the glycosylation pattern of bioactive compounds. Trends Biotechnol. 2001, 19, 449-456. [CrossRef]

20. Brusotti, G.; Cesari, I.; Dentamaro, A.; Caccialanza, G.; Massolini, G. Isolation and characterization of bioactive compounds from plant resources: The role of analysis in the ethnopharmacological approach. J. Pharm. Biomed. Anal. 2014, 87, 218-228. [CrossRef] [PubMed]

21. Mollica, A.; Locatelli, M.; Stefanucci, A.; Pinnen, F. Synthesis and bioactivity of secondary metabolites from marine sponges containing dibrominated indolic systems. Molecules 2012, 17, 6083-6099. [CrossRef] [PubMed]

22. Haefner, B. Drugs from the deep: Marine natural products as drug candidates. Drug Discov. Today 2003, 8, 536-544. [CrossRef]

23. Newman, D.J.; Cragg, G.M. Marine natural products and related compounds in clinical and advanced preclinical trials. J. Nat. Prod. 2004, 67, 1216-1238. [CrossRef]

24. Locatelli, M.; Governatori, L.; Carlucci, G.; Genovese, S.; Mollica, A.; Epifano, F. Recent application of analytical methods to phase I and phase II drugs development: A review. Biomed. Chromatogr. 2012, 26, 283-300. [CrossRef] [PubMed]

25. Abbas, S.; Kelly, M.; Bowling, J.; Sims, J.; Waters, A.; Hamann, M. Advancement into the Arctic region for bioactive sponge secondary metabolites. Mar. Drugs 2011, 9, 2423-2437. [CrossRef] [PubMed]

26. Laport, M.S.; Santos, O.C.S.; Muricy, G. Marine sponges: Potential sources of new antimicrobial drugs. Curr. Pharm. Biotechnol. 2009, 10, 86-105. [CrossRef] [PubMed]

27. Blunt, J.W.; Copp, B.R.; Keyzers, R.A.; Munro, M.H.G.; Prinsep, M.R. Marine natural products. Nat. Prod. Rep. 2012, 29, 144-222. [CrossRef]

28. Valentin, B.B.; Vinod, V.; Beulah, M.C. Biopotential of secondary metabolites isolated from marine sponge Dendrilla nigra. Asian Pac. J. Trop. Dis. 2011, 1, 299-303. [CrossRef]

29. Rönsberg, D.; Debbab, A.; Mándi, A.; Wray, V.; Dai, H.; Kurtán, T.; Proksch, P.; Aly, A.H. Secondary metabolites from the endophytic fungus Pestalotiopsis virgatula isolated from the mangrove plant Sonneratia caseolaris. Tetrahedron Lett. 2013, 54, 3256-3259. [CrossRef]

30. Niu, G.; Li, W. Next-generation drug discovery to combat antimicrobial resistance. Trends Biochem. Sci. 2019, 44, 961-972. [CrossRef]

31. Saleem, M.; Tousif, M.I.; Riaz, N.; Ahmed, I.; Schulz, B.; Ashraf, M.; Nasar, R.; Pescitelli, G.; Hussain, H.; Jabbar, A. Cryptosporioptide: A bioactive polyketide produced by an endophytic fungus Cryptosporiopsis sp. Phytochemistry 2013, 93, 199-202. [CrossRef]

32. Charyulu, E.M.; Sekaran, G.; Rajakumar, G.S.; Gnanamani, A. Antimicrobial Activity of Secondary Metabolite from Marine Isolate, Pseudomonas Sp. Against Gram Positive and Negative Bacteria Including MRSA. Indian J. Exp. Biol. 2009, 47, 964-968.

33. Manivasagan, P.; Venkatesan, J.; Sivakumar, K.; Kim, S.-K. Pharmaceutically active secondary metabolites of marine actinobacteria. Microbiol. Res. 2014, 169, 262-278. [CrossRef]

34. Fenical, W. Chemical studies of marine bacteria: Developing a new resource. Chem. Rev. 1993, 93, $1673-1683$. [CrossRef]

35. Fleming, A. On the antibacterial action of cultures of a penicillium, with special reference to their use in the isolation of B. influenzae. Rev. Infect. Dis. 1980, 129-139. [CrossRef]

36. Shaaban, K.A.; Shepherd, M.D.; Ahmed, T.A.; Nybo, S.E.; Leggas, M.; Rohr, J. Pyramidamycins AD and 3-hydroxyquinoline-2-carboxamide; cytotoxic benzamides from Streptomyces sp. DGC1. J. Antibiot. 2012, 65, 615-622. [CrossRef] [PubMed]

37. Clardy, J.; Fischbach, M.A.; Walsh, C.T. New antibiotics from bacterial natural products. Nat. Biotechnol. 2006, 24, 1541-1550. [CrossRef]

38. Ceniceros, A.; Dijkhuizen, L.; Petrusma, M.; Medema, M.H. Genome-based exploration of the specialized metabolic capacities of the genus Rhodococcus. BMC Genom. 2017, 18, 593. [CrossRef] 
39. Agarwal, V.; Blanton, J.M.; Podell, S.; Taton, A.; Schorn, M.A.; Busch, J.; Lin, Z.; Schmidt, E.W.; Jensen, P.R.; Paul, V.J. Metagenomic discovery of polybrominated diphenyl ether biosynthesis by marine sponges. Nat. Chem. Biol. 2017, 13, 537. [CrossRef]

40. Ueoka, R.; Bhushan, A.; Probst, S.I.; Bray, W.M.; Lokey, R.S.; Linington, R.G.; Piel, J. Genome-Based Identification of a Plant-Associated Marine Bacterium as a Rich Natural Product Source. Angew. Chem. 2018, 130, 14727-14731. [CrossRef]

41. Wang, L.; Ravichandran, V.; Yin, Y.; Yin, J.; Zhang, Y. Natural products from mammalian gut microbiota. Trends Biotechnol. 2019, 37, 492-504. [CrossRef]

42. Chevrette, M.G.; Carlson, C.M.; Ortega, H.E.; Thomas, C.; Ananiev, G.E.; Barns, K.J.; Book, A.J.; Cagnazzo, J.; Carlos, C.; Flanigan, W. The antimicrobial potential of Streptomyces from insect microbiomes. Nat. Commun. 2019, 10, 1-11. [CrossRef]

43. Stewart, E.J. Growing unculturable bacteria. J. Bacteriol. 2012, 194, 4151-4160. [CrossRef]

44. Strobel, G.; Daisy, B.; Castillo, U.; Harper, J. Natural products from endophytic microorganisms. J. Nat. Prod. 2004, 67, 257-268. [CrossRef] [PubMed]

45. Butler, M.S. The role of natural product chemistry in drug discovery. J. Nat. Prod. 2004, 67, 2141-2153. [CrossRef] [PubMed]

46. Flisiak, R.; Horban, A.; Gallay, P.; Bobardt, M.; Selvarajah, S.; Wiercinska-Drapalo, A.; Siwak, E.; Cielniak, I.; Higersberger, J.; Kierkus, J. The cyclophilin inhibitor Debio-025 shows potent anti-hepatitis C effect in patients coinfected with hepatitis C and human immunodeficiency virus. Hepatology 2008, 47, 817-826. [CrossRef] [PubMed]

47. Mahesh, N.; Balakumar, S.; Indumathi, P.; Ayyadurai, A.; Vivek, R. Production and optimization of mevastatin using Penicillium citrinum NCIM 768. J. Microb Biochem. Technol. 2012, 4, 1-4. [CrossRef]

48. López, J.L.C.; Pérez, J.A.S.; Sevilla, J.M.F.; Fernández, F.G.A.; Grima, E.M.; Chisti, Y. Production of lovastatin by Aspergillus terreus: Effects of the $\mathrm{C}: \mathrm{N}$ ratio and the principal nutrients on growth and metabolite production. Enzyme Microb. Technol. 2003, 33, 270-277. [CrossRef]

49. Dewick, P.M. Medicinal Natural Products: A Biosynthetic Approach; John Wiley \& Sons: Hoboken, NJ, USA, 2002; ISBN 0471496413.

50. Balba, H. Review of strobilurin fungicide chemicals. J. Environ. Sci. Heal. Part B 2007, 42, 441-451. [CrossRef]

51. Petrini, O. Fungal endophytes of tree leaves. In Microbial Ecology of Leaves; Springer: Berlin/Heidelberg, Germany, 1991; pp. 179-197.

52. Hyde, K.D.; Soytong, K. The fungal endophyte dilemma. Fungal Divers. 2008, 33, e173.

53. Arnold, A.E. Understanding the diversity of foliar endophytic fungi: Progress, challenges, and frontiers. Fungal Biol. Rev. 2007, 21, 51-66. [CrossRef]

54. Aly, A.H.; Debbab, A.; Kjer, J.; Proksch, P. Fungal endophytes from higher plants: A prolific source of phytochemicals and other bioactive natural products. Fungal Divers. 2010, 41, 1-16. [CrossRef]

55. Kusari, S.; Verma, V.C.; Lamshoeft, M.; Spiteller, M. An endophytic fungus from Azadirachta indica A. Juss. that produces azadirachtin. World J. Microbiol. Biotechnol. 2012, 28, 1287-1294. [CrossRef]

56. Zhang, P.; Zhou, P.; Jiang, C.; Yu, H.; Yu, L. Screening of taxol-producing fungi based on PCR amplification from Taxus. Biotechnol. Lett. 2008, 30, 2119. [CrossRef]

57. Shen, L.; Shi, D.; Song, Y.; Tan, R. Chemical constituents of liquid culture of endophyte IFB-E012 in Artemisia annua. Chin. J. Nat. Med. 2009, 7, 354-356. [CrossRef]

58. Kour, A.; Shawl, A.S.; Rehman, S.; Sultan, P.; Qazi, P.H.; Suden, P.; Khajuria, R.K.; Verma, V. Isolation and identification of an endophytic strain of Fusarium oxysporum producing podophyllotoxin from Juniperus recurva. World J. Microbiol. Biotechnol. 2008, 24, 1115-1121. [CrossRef]

59. Weber, D.; Sterner, O.; Anke, T.; Gorzalczancy, S.; Martino, V.; Acevedo, C. Phomol, a new antiinflammatory metabolite from an endophyte of the medicinal plant Erythrina crista-galli. J. Antibiot. 2004, 57, 559-563. [CrossRef] [PubMed]

60. Kusari, S.; Pandey, S.P.; Spiteller, M. Untapped mutualistic paradigms linking host plant and endophytic fungal production of similar bioactive secondary metabolites. Phytochemistry 2013, 91, 81-87. [CrossRef]

61. Stierle, A.; Strobel, G.; Stierle, D. Taxol and taxane production by Taxomyces andreanae, an endophytic fungus of Pacific yew. Science 1993, 260, 214-216. [CrossRef] 
62. Kusari, S.; Zuühlke, S.; Spiteller, M. Effect of artificial reconstitution of the interaction between the plant Camptotheca acuminata and the fungal endophyte Fusarium solani on camptothecin biosynthesis. J. Nat. Prod. 2011, 74, 764-775. [CrossRef]

63. Eyberger, A.L.; Dondapati, R.; Porter, J.R. Endophyte fungal isolates from Podophyllum peltatum produce podophyllotoxin. J. Nat. Prod. 2006, 69, 1121-1124. [CrossRef]

64. Kusari, S.; Lamshöft, M.; Spiteller, M. Aspergillus fumigatus Fresenius, an endophytic fungus from Juniperus communis L. Horstmann as a novel source of the anticancer pro-drug deoxypodophyllotoxin. J. Appl. Microbiol. 2009, 107, 1019-1030. [CrossRef]

65. Kusari, S.; Zuühlke, S.; Kosuth, J.; Cellarova, E.; Spiteller, M. Light-independent metabolomics of endophytic Thielavia subthermophila provides insight into microbial hypericin biosynthesis. J. Nat. Prod. 2009, 72, 1825-1835. [CrossRef]

66. Blunt, J.W.; Copp, B.R.; Keyzers, R.A.; Munro, M.H.G.; Prinsep, M.R. Marine natural products. Nat. Prod. Rep. 2014, 31, 160-258. [CrossRef] [PubMed]

67. Berdy, J. The discovery of new bioactive microbial metabolites: Screening and identification. Prog. Ind. Microbiol. 1989, 27, 3-27.

68. Kämpfer, P. The family Streptomycetaceae, part I: Taxonomy. Prokaryotes 2006, 3, 538-604.

69. Yarza, P.; Richter, M.; Peplies, J.; Euzeby, J.; Amann, R.; Schleifer, K.-H.; Ludwig, W.; Glöckner, F.O.; Rosselló-Móra, R. The All-Species Living Tree project: A 16S rRNA-based phylogenetic tree of all sequenced type strains. Syst. Appl. Microbiol. 2008, 31, 241-250. [CrossRef] [PubMed]

70. Chater, K.F. Regulation of sporulation in Streptomyces coelicolor A3 (2): A checkpoint multiplex? Curr. Opin. Microbiol. 2001, 4, 667-673. [CrossRef]

71. Kimura, K.; Kanou, F.; Takahashi, H.; Esumi, Y.; Uramoto, M.; Yoshihama, M. Propeptin, a New Inhibitor of Prolyl Endopeptidase Produced by Microbispora. J. Antibiot. 1997, 50, 373-378. [CrossRef] [PubMed]

72. Sun, C.-H.; Wang, Y.; Wang, Z.; Zhou, J.-Q.; Jin, W.-Z.; You, X.-F.; Gao, H.; Zhao, L.-X.; Si, S.-Y.; Li, X. Chemomicin A, a new angucyclinone antibiotic produced by Nocardia mediterranei subsp. kanglensis 1747-64. J. Antibiot. 2007, 60, 211-215. [CrossRef]

73. Hatsu, M.; Sasaki, T.; Gomi, S.; Kodama, Y.; Sezaki, M.; Inouye, S.; Kondo, S. A new tetracycline antibiotic with antitumor activity. J. Antibiot. 1992, 45, 325-330. [CrossRef]

74. Maskey, R.P.; Kock, I.; Helmke, E.; Laatsch, H. Isolation and Structure Determination of Phenazostatin D, a New Phenazine froma Marine Actinomycete Isolate Pseudonocardia sp. B6273. Z. Für Naturforsch. B 2003, 58, 692-694. [CrossRef]

75. Tanaka, Y.; Komaki, H.; Yazawa, K.; Mikami, Y.; Nemoto, A.; Tojyo, T.; Kadowaki, K.; Shigemori, H.; Kobayashi, J. Brasilinolide A, a new macrolide antibiotic produced by Nocardia brasiliensis: Producing strain, isolation and biological activity. J. Antibiot. 1997, 50, 1036-1041. [CrossRef]

76. Takahashi, I.; Takahashi, K.-I.; Asano, K.; Kawamoto, I.; Yasuzawa, T.; Ashizawat, T.; Tomita, F.; Nakano, H. DC92-B, a new antitumor antibiotic from Actinomadura. J. Antibiot. 1988, 41, 1151-1153. [CrossRef] [PubMed]

77. Lemriss, S.; Laurent, F.; Couble, A.; Casoli, E.; Lancelin, J.M.; Saintpierre-Bonaccio, D.; Rifai, S.; Fassouane, A.; Boiron, P. Screening of nonpolyenic antifungal metabolites produced by clinical isolates of actinomycetes. Can. J. Microbiol. 2003, 49, 669-674. [CrossRef] [PubMed]

78. Maeda, A.; Nagai, H.; Yazawa, K.; Tanaka, Y.; Imai, T.; Mikami, Y.; Kuramochi, T.; Yamazaki, C. Three new reduced anthracycline related compounds from pathogenic Nocardia brasiliensis. J. Antibiot. 1994, 47, 976-981. [CrossRef] [PubMed]

79. Aoki, H.; Sakai, H.-I.; Kohsaka, M.; Konomi, T.; Hosoda, J.; Kubochi, Y.; Iguchi, E.; Imanaka, H. Nocardicin A, a new monocyclic $\beta$-lactam antibiotic. J. Antibiot. 1976, 29, 492-500. [CrossRef]

80. Hayakawa, Y.; Shirasaki, S.; Shiba, S.; Kawasaki, T.; Matsuo, Y.; Adachi, K.; Shizuri, Y. Piericidins C 7 and C 8 , New Cytotoxic Antibiotics Produced by a Marine Streptomyces sp. J. Antibiot. 2007, 60, 196-200. [CrossRef]

81. Radzom, M.; Zeeck, A.; Antal, N.; Fiedler, H.-P. Fogacin, a novel cyclic octaketide produced by Streptomyces strain Tü 6319. J. Antibiot. 2006, 59, 315-317. [CrossRef]

82. Doull, J.L.; Singh, A.K.; Hoare, M.; Ayer, S.W. Conditions for the production of jadomycin B byStreptomyces venezuelae ISP5230: Effects of heat shock, ethanol treatment and phage infection. J. Ind. Microbiol. 1994, 13, 120-125. [CrossRef] 
83. Singh, M.P.; Petersen, P.J.; Weiss, W.J.; Kong, F.; Greenstein, M. Saccharomicins, novel heptadecaglycoside antibiotics produced by Saccharothrix espanaensis: Antibacterial and mechanistic activities. Antimicrob. Agents Chemother. 2000, 44, 2154-2159. [CrossRef]

84. Imai, H.; Suzuki, K.-I.; Morioka, M.; Numasaki, Y.; Kadota, S.; Nagai, K.; Sato, T.; Iwanami, M.; Saito, T. Okilactomycin, a novel antibiotic produced by a Streptomyces species. J. Antibiot. 1987, 40, 1475-1482. [CrossRef]

85. Bibb, M.J. Regulation of secondary metabolism in streptomycetes. Curr. Opin. Microbiol. 2005, 8, $208-215$. [CrossRef]

86. Gesheva, V.; Ivanova, V.; Gesheva, R. Effects of nutrients on the production of AK-111-81 macrolide antibiotic by Streptomyces hygroscopicus. Microbiol. Res. 2005, 160, 243-248. [CrossRef] [PubMed]

87. Weber, T.; Welzel, K.; Pelzer, S.; Vente, A.; Wohlleben, W. Exploiting the genetic potential of polyketide producing streptomycetes. J. Biotechnol. 2003, 106, 221-232. [CrossRef] [PubMed]

88. Corbin, D.R.; Greenplate, J.T.; Wong, E.Y.; Purcell, J.P. Cloning of an insecticidal cholesterol oxidase gene and its expression in bacteria and in plant protoplasts. Appl. Environ. Microbiol. 1994, 60, 4239-4244. [CrossRef] [PubMed]

89. Hopwood, D.A. Forty years of genetics with Streptomyces: From in vivo through in vitro to in silico. Microbiology 1999, 145, 2183-2202. [CrossRef]

90. Brautaset, T.; Sekurova, O.N.; Sletta, H.; Ellingsen, T.E.; Strøm, A.R.; Valla, S.; Zotchev, S.B. Biosynthesis of the polyene antifungal antibiotic nystatin in Streptomyces noursei ATCC 11455: Analysis of the gene cluster and deduction of the biosynthetic pathway. Chem. Biol. 2000, 7, 395-403. [CrossRef]

91. Raja, A.; Prabakarana, P. Actinomycetes and drug-an overview. Am. J. Drug Discov. Dev. 2011, 1, 75-84. [CrossRef]

92. Meanwell, R.J.L.; Shama, G. Production of streptomycin from chitin using Streptomyces griseus in bioreactors of different configuration. Bioresour. Technol. 2008, 99, 5634-5639. [CrossRef]

93. Dulmage, H.T. The production of neomycin by Streptomyces fradiae in synthetic media. Appl. Microbiol. 1953, 1, 103. [CrossRef]

94. Yanai, K.; Murakami, T. The kanamycin biosynthetic gene cluster from Streptomyces kanamyceticus. J. Antibiot. 2004, 57, 351-354. [CrossRef]

95. Petković, H.; Cullum, J.; Hranueli, D.; Hunter, I.S.; Perić-Concha, N.; Pigac, J.; Thamchaipenet, A.; Vujaklija, D.; Long, P.F. Genetics of Streptomyces rimosus, the oxytetracycline producer. Microbiol. Mol. Biol. Rev. 2006, 70, 704-728. [CrossRef]

96. Vitayakritsirikul, V.; Jaemsaeng, R.; Lohmaneeratana, K.; Thanapipatsiri, A.; Daduang, R.; Chuawong, P.; Thamchaipenet, A. Improvement of chloramphenicol production in Streptomyces venezuelae ATCC 10712 by overexpression of the aroB and aroK genes catalysing steps in the shikimate pathway. Antonie Van Leeuwenhoek 2016, 109, 379-388. [CrossRef] [PubMed]

97. Williamson, J.M.; Inamine, E.; Wilson, K.E.; Douglas, A.W.; Liesch, J.M.; Albers-Schönberg, G. Biosynthesis of the beta-lactam antibiotic, thienamycin, by Streptomyces cattleya. J. Biol. Chem. 1985, 260, 4637-4647. [PubMed]

98. Zhanel, G.G.; Homenuik, K.; Nichol, K.; Noreddin, A.; Vercaigne, L.; Embil, J.; Gin, A.; Karlowsky, J.A.; Hoban, D.J. The glycylcyclines. Drugs 2004, 64, 63-88. [CrossRef] [PubMed]

99. Chapman, T.M.; Perry, C.M. Everolimus. Drugs 2004, 64, 861-872. [CrossRef]

100. Broggini, M.; Marchini, S.; Fontana, E.; Moneta, D.; Fowst, C.; Geroni, C. Brostallicin: A new concept in minor groove DNA binder development. Anticancer. Drugs 2004, 15, 1-6. [CrossRef]

101. Salas, J.A.; Méndez, C. yGenetic manipulation of antitumor-agent biosynthesis to produce novel drugs. Trends Biotechnol. 1998, 16, 475-482. [CrossRef]

102. Khosla, C.; Zawada, R.J.X. Generation of polyketide libraries via combinatorial biosynthesis. Trends Biotechnol. 1996, 14, 335-341. [CrossRef]

103. Watve, M.G.; Tickoo, R.; Jog, M.M.; Bhole, B.D. How many antibiotics are produced by the genus Streptomyces? Arch. Microbiol. 2001, 176, 386-390. [CrossRef]

104. Qin, S.; Xing, K.; Jiang, J.-H.; Xu, L.-H.; Li, W.-J. Biodiversity, bioactive natural products and biotechnological potential of plant-associated endophytic actinobacteria. Appl. Microbiol. Biotechnol. 2011, 89, 457-473. [CrossRef] 
105. Janso, J.E.; Carter, G.T. Biosynthetic potential of phylogenetically unique endophytic actinomycetes from tropical plants. Appl. Environ. Microbiol. 2010, 76, 4377-4386. [CrossRef]

106. Kupchan, S.M. Maytansine, a novel antileukemic ansa macrolide from Maytenus ovatus. J. Am. Chem. Soc. 1972, 94, 1354-1356. [CrossRef] [PubMed]

107. Powell, R.G.; Weisleder, D.; Smith Jr, C.R.; Kozlowski, J.; Rohwedder, W.K. Treflorine, trenudine, and N-methyltrenudone: Novel maytansinoid tumor inhibitors containing two fused macrocyclic rings. J. Am. Chem. Soc. 1982, 104, 4929-4934. [CrossRef]

108. Suwanborirux, K.; Chang, C.-J.; Spjut, R.W.; Cassady, J.M. Ansamitocin P-3, a maytansinoid, fromClaopodium crispifolium andAnomodon attenuatus or associated actinomycetes. Experientia 1990, 46, 117-120. [CrossRef] [PubMed]

109. Higashide, E.; Asai, M.; Ootsu, K.; Tanida, S.; Kozai, Y.; Hasegawa, T.; Kishi, T.; Sugino, Y.; Yoneda, M. Ansamitocin, a group of novel maytansinoid antibiotics with antitumour properties from Nocardia. Nature 1977, 270, 721-722. [CrossRef]

110. Taechowisan, T.; Lu, C.; Shen, Y.; Lumyong, S. 4-arylcoumarin inhibits immediate-type allergy. Food Agric. Immunol. 2007, 18, 203-211. [CrossRef]

111. El-Tarabily, K.A.; Nassar, A.H.; Hardy, G.E.S.J.; Sivasithamparam, K. Plant growth promotion and biological control of Pythium aphanidermatum, a pathogen of cucumber, by endophytic actinomycetes. J. Appl. Microbiol. 2009, 106, 13-26. [CrossRef]

112. Shimizu, M.; Yazawa, S.; Ushijima, Y. A promising strain of endophytic Streptomyces sp. for biological control of cucumber anthracnose. J. Gen. Plant. Pathol. 2009, 75, 27-36. [CrossRef]

113. Merzaeva, O.V.; Shirokikh, I.G. The production of auxins by the endophytic bacteria of winter rye. Appl. Biochem. Microbiol. 2010, 46, 44-50. [CrossRef]

114. Wohlleben, W.; Mast, Y.; Muth, G.; Röttgen, M.; Stegmann, E.; Weber, T. Synthetic biology of secondary metabolite biosynthesis in actinomycetes: Engineering precursor supply as a way to optimize antibiotic production. FEBS Lett. 2012, 586, 2171-2176. [CrossRef]

115. Medema, M.H.; Breitling, R.; Takano, E. Synthetic biology in Streptomyces bacteria. In Methods in Enzymology; Elsevier: Amsterdam, The Netherlands, 2011; Volume 497, pp. 485-502. ISBN 0076-6879.

116. Zaehner, H.; Fiedler, H.-P. The need for new antibiotics: Possible ways forward. In Proceedings of the Symposia-Society for General MIcrobiology; Cambridge University Press: Cambridge, UK, 1995; Volume 1, p. 67.

117. Nakagawa, A.; Omura, S. Biosynthesis of bioactive microbial metabolites and its application to the structural studies and production of hybrid compounds. J. Antibiot. 1996, 49, 717-741. [CrossRef]

118. Moellering, R.C. Linezolid: The first oxazolidinone antimicrobial. Ann. Intern. Med. 2003, $139,864$. [CrossRef]

119. World Health Organization. Report and Proceedings of a WHO Meeting in Berlin, Germany, 13-17 October 1997. WHO EM CL 2001, 97, 4.

120. Bentley, S.D.; Chater, K.F.; Cerdeño-Tárraga, A.-M.; Challis, G.L.; Thomson, N.R.; James, K.D.; Harris, D.E.; Quail, M.A.; Kieser, H.; Harper, D. Complete genome sequence of the model actinomycete Streptomyces coelicolor A3 (2). Nature 2002, 417, 141-147. [CrossRef] [PubMed]

121. Ikeda, H.; Ishikawa, J.; Hanamoto, A.; Shinose, M.; Kikuchi, H.; Shiba, T.; Sakaki, Y.; Hattori, M.; Ōmura, S. Complete genome sequence and comparative analysis of the industrial microorganism Streptomyces avermitilis. Nat. Biotechnol. 2003, 21, 526. [CrossRef] [PubMed]

122. Ramesh, S.; Mathivanan, N. Screening of marine actinomycetes isolated from the Bay of Bengal, India for antimicrobial activity and industrial enzymes. World J. Microbiol. Biotechnol. 2009, 25, 2103-2111. [CrossRef]

123. Xiao, J.; Luo, Y.; Xie, S.; Xu, J. Serinicoccus profundi sp. nov., an actinomycete isolated from deep-sea sediment, and emended description of the genus Serinicoccus. Int. J. Syst. Evol. Microbiol. 2011, 61, 16-19. [CrossRef]

124. Oh, D.-C.; Gontang, E.A.; Kauffman, C.A.; Jensen, P.R.; Fenical, W. Salinipyrones and pacificanones, mixed-precursor polyketides from the marine actinomycete Salinispora pacifica. J. Nat. Prod. 2008, 71, 570-575. [CrossRef]

125. Jensen, P.R.; Williams, P.G.; Oh, D.-C.; Zeigler, L.; Fenical, W. Species-specific secondary metabolite production in marine actinomycetes of the genus Salinispora. Appl. Environ. Microbiol. 2007, 73, 1146-1152. [CrossRef]

126. Maloney, K.N.; MacMillan, J.B.; Kauffman, C.A.; Jensen, P.R.; DiPasquale, A.G.; Rheingold, A.L.; Fenical, W. Lodopyridone, a structurally unprecedented alkaloid from a marine actinomycete. Org. Lett. 2009, 11, 5422-5424. [CrossRef] 
127. Asolkar, R.N.; Kirkland, T.N.; Jensen, P.R.; Fenical, W. Arenimycin, an antibiotic effective against rifampin-and methicillin-resistant Staphylococcus aureus from the marine actinomycete Salinispora arenicola. J. Antibiot. 2010, 63, 37-39. [CrossRef]

128. Dias, D.A.; Urban, S.; Roessner, U. A historical overview of natural products in drug discovery. Metabolites 2012, 2, 303-336. [CrossRef] [PubMed]

129. Zhang, C.; Straight, P.D. Antibiotic discovery through microbial interactions. Curr. Opin. Microbiol. 2019, 51, 64-71. [CrossRef] [PubMed]

130. Zhanel, G.G.; Walters, M.; Noreddin, A.; Vercaigne, L.M.; Wierzbowski, A.; Embil, J.M.; Gin, A.S.; Douthwaite, S.; Hoban, D.J. The ketolides. Drugs 2002, 62, 1771-1804. [CrossRef] [PubMed]

131. Perry, C.M.; Ibbotson, T. Biapenem. Drugs 2002, 62, 2221-2234. [CrossRef]

132. Keating, G.M.; Perry, C.M. Ertapenem. Drugs 2005, 65, 2151-2178. [CrossRef] [PubMed]

133. Pastores, G.M.; Barnett, N.L.; Kolodny, E.H. An open-label, noncomparative study of miglustat in type I Gaucher disease: Efficacy and tolerability over 24 months of treatment. Clin. Ther. 2005, 27, 1215-1227. [CrossRef]

134. Fenton, C.; Keating, G.M.; Curran, M.P. Daptomycin. Drugs 2004, 64, 445-455. [CrossRef]

135. Sugiura, T.; Ariyoshi, Y.; Negoro, S.; Nakamura, S.; Ikegami, H.; Takada, M.; Yana, T.; Fukuoka, M. Phase I/II study of amrubicin, a novel 9-aminoanthracycline, in patients with advanced non-small-cell lung cancer. Investig. New Drugs 2005, 23, 331-337. [CrossRef]

136. Gupta, A.K.; Chow, M. Pimecrolimus: A review. J. Eur. Acad. Dermatol. Venereol. 2003, 17, $493-503$. [CrossRef]

137. Guiry, M.D. How many species of algae are there? J. Phycol. 2012, 48, 1057-1063. [CrossRef]

138. Abdel-Razek, A.S.; Hamed, A.; Frese, M.; Sewald, N.; Shaaban, M. Penicisteroid C: New polyoxygenated steroid produced by co-culturing of Streptomyces piomogenus with Aspergillus niger. Steroids 2018, 138, 21-25. [CrossRef] [PubMed]

139. Leal, M.C.; Munro, M.H.G.; Blunt, J.W.; Puga, J.; Jesus, B.; Calado, R.; Rosa, R.; Madeira, C. Biogeography and biodiscovery hotspots of macroalgal marine natural products. Nat. Prod. Rep. 2013, 30, 1380-1390. [CrossRef] [PubMed]

140. Vuong, Q.V. Utilisation of Bioactive Compounds from Agricultural and Food Production Waste; CRC Press: Boca Raton, FL, USA, 2017; ISBN 1351647598.

141. Tringali, C.; Oriente, G.; Piattelli, M.; Geraci, C.; Nicolosi, G.; Breitmaier, E. Crenuladial, an antimicrobial diterpenoid from the brown alga Dilophus ligulatus. Can. J. Chem. 1988, 66, 2799-2802. [CrossRef]

142. Topcu, G.; Aydogmus, Z.; Imre, S.; Gören, A.C.; Pezzuto, J.M.; Clement, J.A.; Kingston, D.G.I. Brominated Sesquiterpenes from the Red Alga Laurencia o btusa. J. Nat. Prod. 2003, 66, 1505-1508. [CrossRef] [PubMed]

143. Butler, G.L. Algae and pesticides. In Residue Reviews; Springer: Berlin/Heidelberg, Germany, 1977; pp. 19-62.

144. Zuck, K.M.; Shipley, S.; Newman, D.J. Induced production of N-formyl alkaloids from Aspergillus fumigatus by co-culture with Streptomyces peucetius. J. Nat. Prod. 2011, 74, 1653-1657. [CrossRef]

145. Cueto, M.; Jensen, P.R.; Kauffman, C.; Fenical, W.; Lobkovsky, E.; Clardy, J. Pestalone, a new antibiotic produced by a marine fungus in response to bacterial challenge. J. Nat. Prod. 2001, 64, 1444-1446. [CrossRef]

146. Oh, D.-C.; Jensen, P.R.; Kauffman, C.A.; Fenical, W. Libertellenones A-D: Induction of cytotoxic diterpenoid biosynthesis by marine microbial competition. Bioorg. Med. Chem. 2005, 13, 5267-5273. [CrossRef]

147. Oh, D.-C.; Kauffman, C.A.; Jensen, P.R.; Fenical, W. Induced production of emericellamides A and B from the marine-derived fungus Emericella sp. in competing co-culture. J. Nat. Prod. 2007, 70, 515-520. [CrossRef]

148. Park, H.B.; Kwon, H.C.; Lee, C.-H.; Yang, H.O. Glionitrin A, an antibiotic-Antitumor metabolite derived from competitive interaction between abandoned mine microbes. J. Nat. Prod. 2009, 72, 248-252. [CrossRef]

149. Hoshino, S.; Zhang, L.; Awakawa, T.; Wakimoto, T.; Onaka, H.; Abe, I. Arcyriaflavin E, a new cytotoxic indolocarbazole alkaloid isolated by combined-culture of mycolic acid-containing bacteria and Streptomyces cinnamoneus NBRC 13823. J. Antibiot. 2015, 68, 342-344. [CrossRef]

150. Hoshino, S.; Wakimoto, T.; Onaka, H.; Abe, I. Chojalactones A-C, cytotoxic butanolides isolated from Streptomyces sp. cultivated with mycolic acid containing bacterium. Org. Lett. 2015, 17, 1501-1504. [CrossRef] [PubMed] 
151. Hoshino, S.; Okada, M.; Wakimoto, T.; Zhang, H.; Hayashi, F.; Onaka, H.; Abe, I. Niizalactams A-C, multicyclic macrolactams isolated from combined culture of Streptomyces with mycolic acid-containing bacterium. J. Nat. Prod. 2015, 78, 3011-3017. [CrossRef] [PubMed]

152. Adnani, N.; Chevrette, M.G.; Adibhatla, S.N.; Zhang, F.; Yu, Q.; Braun, D.R.; Nelson, J.; Simpkins, S.W.; McDonald, B.R.; Myers, C.L. Coculture of marine invertebrate-associated bacteria and interdisciplinary technologies enable biosynthesis and discovery of a new antibiotic, keyicin. ACS Chem. Biol. 2017, 12, 3093-3102. [CrossRef] [PubMed]

(C) 2020 by the authors. Licensee MDPI, Basel, Switzerland. This article is an open access article distributed under the terms and conditions of the Creative Commons Attribution (CC BY) license (http://creativecommons.org/licenses/by/4.0/). 